\title{
The Immune-Modulating Cytokine and Endogenous Alarmin Interleukin-33 Is Upregulated in Skin Exposed to Inflammatory UVB Radiation
}

\author{
Scott Napier Byrne, ${ }^{* \dagger}$ Clare Beaugie, ${ }^{* \dagger}$ \\ Clare O'Sullivan, ${ }^{* \dagger}$ Sarah Leighton, ${ }^{* \dagger}$ and \\ Gary M. Halliday ${ }^{\dagger}$ \\ From the Cellular Immunology Group, * Department of \\ Infectious Diseases and Immunology, and the Dermatology \\ Research Laboratories, ${ }^{\dagger}$ Discipline of Dermatology, Bosch \\ Institute, Sydney Medical School, University of Sydney, New \\ South Wales, Australia
}

The cellular and molecular mechanisms by which UV radiation modulates inflammation and immunity while simultaneously maintaining skin homeostasis is complex and not completely understood. Similar to the effects of UV, IL-33 has potent immune-modulating properties that are mediated by the downstream induction of cytokines and chemokines. We have discovered that exposure of mice in vivo or human skin samples ex vivo to inflammatory doses of UVB induced II-33 expression within the epidermal and dermal skin layers. Using a combination of murine cell lines and primary human cells, we demonstrate that both UV and the oxidized lipid platelet activating factor induce IL-33 expression in keratinocytes and dermal fibroblasts. Highlighting the significance of these results, we found that administering II-33 to mice in vivo suppressed the induction of Th1-mediated contact hypersensitivity responses. This may have consequences for skin cancer growth because UV-induced squamous cell carcinomas that evade immunological destruction were found to express significantly higher levels of IL-33. Finally, we demonstrate that dermal mast cells and skininfiltrating neutrophils closely associate with UV-induced II-33-expressing fibroblasts. Our results therefore identify and support a role for $\mathrm{IL}-33$ as an important early danger signal produced in response to inflammation-inducing UV radiation. (Am J Pathol 2011, 179:211-222; DOI: 10.1016/j.ajpath.2011.03.010)

The UV radiation contained in sunlight has wide-ranging immunosuppressive capabilities spanning both the induction and effector phases of an immune response. This property of UV is a key event in skin carcinogenesis ${ }^{1}$; but it may also have beneficial effects, including protection from multiple sclerosis, ${ }^{2}$ enhancing allograft tolerance, ${ }^{3}$ as well as treating psoriasis, ${ }^{4}$ atopic dermatitis, ${ }^{5}$ and graft-versus-host disease. ${ }^{6}$ Other health benefits of UV exposure include vitamin $D$ synthesis ${ }^{7}$ and the production of antimicrobial peptides. ${ }^{8}$ Unfortunately, the exact mechanism by which UV modulates inflammation and immunity is not completely understood, even though understanding these events could lead to the design of novel immune-modulating treatment regimes. UV-induced DNA damage, ${ }^{9}$ together with the production of oxidized lipids ${ }^{10}$ and the release of immune-modulating cytokines (particularly prostaglandin $E_{2}, I L-4$, and IL$10^{11,12}$ ) play important roles. The downstream cellular targets of these UV-induced inflammatory mediators include dendritic cells, ${ }^{13}$ dermal mast cells, ${ }^{12}$ as well as regulatory $\mathrm{T}^{14}$ and $\mathrm{B}$ cells. ${ }^{15,16}$ Consequently, UV is broadly immunosuppressive, having the capacity to suppress the induction and effector phases of CD8-T-cell responses, development of immunological memory, ${ }^{17}$ Th1-driven ${ }^{18}$ and Th2-driven immunity, ${ }^{19}$ as well as antibody-mediated immune responses. ${ }^{20}$

IL-33 (IL-33/IL-1F11/NF-HEV) is a member of the IL-1 family of cytokines. ${ }^{21,22} \mathrm{IL}-33$ exerts its biological function by binding to the ST2 receptor on the surface of T-helper 2 (Th2) cells, ${ }^{22}$ mast cells, ${ }^{22,23}$ basophils, ${ }^{24}$ eosinophils, ${ }^{25}$ NKT cells, ${ }^{26}$ dendritic cells, ${ }^{27}$ and neutrophils. ${ }^{28}$ Similar to the effects of UV, IL-33 has potent immunemodulating properties that are mediated by the induction of cytokines including IL-1, -4, -6, -10. and -13 , as well as chemokines such as CXCL8, CCL2, CCL3, and CCL5. ${ }^{22,23,29,30}$ Consequently, although IL-33 can reduce the development of atheroscleoris ${ }^{31}$ and prevent the development of parasitic-induced encephalitis, ${ }^{32}$ it may also promote the development of asthma ${ }^{33}$ and ar-

Supported by a Cancer Institute NSW Career Development and Support Fellowship (S.N.B.) (07/CDF/01-07) and by Epiderm.

Accepted for publication March 14, 2011.

Address reprint requests to Scott Byrne, Ph.D., Infectious Diseases and Immunology, Room 676, Blackburn Building, D06, University of Sydney, NSW 2006, Australia. E-mail: scott.byrne@sydney.edu.au. 
thritis. ${ }^{29}$ Recently, the immune-modulating functions of IL-33 have been extended to include attenuation of bacterial sepsis via neutrophil recruitment ${ }^{28}$ and the activation of newly discovered "nuocytes" for the effective elimination of parasitic infections. ${ }^{34}$

A number of cellular sources for IL-33 have been reported, including endothelial cells, epithelial cells, and fibroblasts. In the skin, IL-33 is constitutively expressed in epidermal keratinocytes ${ }^{35}$ and is significantly upregulated in inflamed skin samples of atopic dermatitis patients. ${ }^{36}$ It has been hypothesized that IL-33 acts as a novel "alarmin" that is released in the full-length active form after tissue damage. ${ }^{35,37}$ In this way, IL-33 acts as an endogenous danger signal that mediates the recruitment of innate immune cells to sites of infection or cellular damage. In support of this hypothesis, we show here that exposure to physiologically relevant doses of inflammatory UVB induces IL-33 in the epithelial layers of murine skin and upregulates IL-33 expression in human epidermis. UVB, but not UVA, radiation also induced de novo expression of IL-33 in dermal fibroblasts. UV-induced epithelial-derived skin tumors that evade immunological destruction also produced significant constitutive amounts of IL-33. IL-33-producing fibroblasts were surrounded by mast cells as well as newly recruited neutrophils, demonstrating the potential for UV-induced IL-33 to enhance innate immunity in the skin and to act as a unique molecular sensor of UV-induced damage.

\section{Materials and Methods}

\section{Cell Lines, Primary Cells, Tissue Samples, and Culture}

\section{Murine Cells and Tissue}

Female C57BL/6 mice (Animal Resource Centre, Perth, WA, Australia) or $\mathrm{P}_{2} \mathrm{X}_{7} \mathrm{R}^{-1-}$ mice ${ }^{38}$ (Centenary Institute; Sydney, Australia), aged 8 to 10 weeks at the start of experiments, were used with approval from the University of Sydney animal ethics committee. Shaved murine skin was exposed to UV and, at various times afterward, irradiated skin samples were collected and either snap frozen for real-time quantitative (q) RT-PCR analysis or were embedded in OCT and snap frozen for histological analysis. Murine embryonic fibroblasts (MEFs) originally derived from $\mathrm{C} 57 \mathrm{BL} / 6$ embryos were cultured as previously described. ${ }^{39}$ The BALB/c-derived immortalized keratinocyte cell line PAM 212 was cultured as described elsewhere. ${ }^{40}$ Details of the two murine UV-induced skin tumor cell lines have been described by us previously. ${ }^{41}$

\section{Human Cells and Tissue}

Normal human skin was obtained from a 35-year-old, fair-skinned, female abdominal surgery patient. Numerous whole skin samples were cultured in complete RPMI1640 before ex vivo UV exposure. Normal human fibroblasts and keratinocyte cultures were derived from a 35-year-old, fair-skinned, female breast reduction surgery patient and maintained in Stemline Keratinocyte Me- dium II with Stemline Keratinocyte Growth Supplement (Sigma, St. Louis, MO). Additional fibroblast cultures were derived from three separate human foreskin samples. Cells were used after the third passage.

\section{UV Source and Irradiation and Treatment of Mice, Cells, and Tissue}

Details of the UV source, shaving, exposure of mice, and monitoring of the UV source have been described by us previously. ${ }^{18}$ Briefly, a $1000-\mathrm{W}$ xenon arc solar simulator (Oriel, Stratford, CT) that expertly recreates the solar UV spectrum, was used to deliver an accurate dose of solarsimulated UV (ssUV; containing both UVA and UVB). In some experiments, spectra containing only UVA or only UVB were used where indicated. The same solar-simulated UV source was used for the in vitro studies. In these experiments, the various murine and human cell lines and primary cells were plated onto chamber slides (BD Falcon, Bedford, MA) at $80 \%$ confluence in $1 \mathrm{~mL}$ of their respective media. Twenty-four hours after incubation at $37^{\circ} \mathrm{C}$ in a $5 \% \mathrm{CO}_{2}$ incubator, the media were removed and replaced with $250 \mu \mathrm{L}$ PBS to ensure that the cells did not dry out, and then the cells or tissue were exposed to UV. The dose of UV used in each experiment is indicated in the respective figure legends. In some experiments, murine fibroblasts were incubated with either $1 \mu \mathrm{mol} / \mathrm{L}$ of carbamyl-PAF (cPAF) (Biomol, Enzo Life Sciences, Farmingdale, NY), $100 \mu \mathrm{g} / \mathrm{mL}$ cis-Urocanic Acid (cis-UCA; Sigma, St. Louis, MO), or PBS for either 1 hour or 4 hours. After UV exposure or treatment, cells were returned to the incubator in their respective media for an additional 24 hours before immunofluorescent analysis. In other experiments, $3.3 \times 10^{5} \mathrm{LK}-2$ regressor or 13-1 progressor tumor cells were plated into T25 flasks (representing 50\% confluence). The cells were then grown as indicated in various concentrations of rIL-33-supplmented complete RPMI1640 ( $10 \%$ fetal calf serum) for 3 days (corresponding to the time that the 13-1 control-treated cells reached $100 \%$ confluence). At this point, all of the cultures were trypsinized and total viable cells counted using a ViCell fully automated cell counter (Beckman Coulter, Brea, CA).

\section{Histology and Immunofluorescence}

Frozen skin tissue sections ( $7 \mu \mathrm{m})$ or Tris-buffered saline (TBS)-washed chamber slide-adherent cells were fixed for 10 minutes in methanol $\left(4^{\circ} \mathrm{C}\right)$. Slides were treated with a biotin blocking kit (X0590; Dako, Carpinteria, CA) as per the manufacturer's instructions before blocking other proteins with $5 \%$ normal equine serum for 1 hour at $25^{\circ} \mathrm{C}$. Slides were then incubated for 18 hours at $4^{\circ} \mathrm{C}$ with 10 $\mu \mathrm{g} / \mathrm{mL}$ goat anti-mouse IL-33 (AF3626; R\&D Systems, Minneapolis, MN), goat anti-human IL-33 (AF3625; R\&D Systems), or purified goat IgG (AB-108-C; R\&D Systems). After this, the TBS-washed slides were incubated for 1 hour at $37^{\circ} \mathrm{C}$ with a $1 / 200$ biotin-conjugated donkey antigoat IgG secondary antibody (705-066-147; Jackson Immunoresearch, West Grove, PA). The slides were then washed in TBS before a 30 -minute incubation at $37^{\circ} \mathrm{C}$ in 
1/1000 strepavidin Alexa Fluor 488 (S-11223; Molecular Probes, Carlsbad, CA). Finally, the slides were mounted and coverslipped in DAPI containing mounting medium (H-1500; Vectorshield, Vector Laboratories, Burlingame, CA) before being photographed immediately. In some experiments, the fluorescently labeled sections were photographed immediately before the removal of the coverslip and subsequent staining of mast cells using toluidine blue as we have described. ${ }^{42}$ For the simultaneous immunofluorescence detection of IL-33 with CD45 or CD117, slides were first labeled for IL-33 as above, substituting the biotin-labeled detecting antibody for a chicken anti-goat Alexa Fluor 488 (Molecular Probes). These slides were then washed and biotin blocked as above before being incubated for 2 hours at $37^{\circ} \mathrm{C}$ with 10 $\mu \mathrm{g} / \mathrm{mL}$ of $\mathrm{BD}$ Biosciences clone 30-F11 (for CD45), 10 $\mu \mathrm{g} / \mathrm{mL}$ Biolegend clone 2B8 (for CD117), or $10 \mu \mathrm{g} / \mathrm{mL}$ of eBioscience rat $\operatorname{lgG}_{2 b}$ isotype control. Rat monoclonals were then visualized using 1/200 preabsorbed biotinylated goat anti-rat Ig (559286; BD Biosciences, San Diego, CA) for 1 hour at $37^{\circ} \mathrm{C}$ followed by $1 / 1000$ strepavidin-AF594 (S-32356; Molecular Probes). The 1A8 rat anti-mouse Ly6G clone (BD Biosciences) was used at $10 \mu \mathrm{g} / \mathrm{mL}$ for 2 hours at $37^{\circ} \mathrm{C}$ to specifically identify neutrophils ${ }^{43}$ in IL-33stained skin sections. Specificity was confirmed using a rat lg $G_{2 a}$ isotype control (clone R35-95; BD Biosciences). Labeled neutrophils were then visualized using 1/200 preabsorbed biotinylated goat anti-rat Ig (559286; BD Biosciences) for 1 hour at $37^{\circ} \mathrm{C}$, followed by $1: 4000$ Strepavidin NL557 (R\&D Systems).

\section{Image Analysis}

For the quantitative analysis of IL-33 intensity in fibroblasts, keratinocytes, and tumor cell lines, fluorescent images were acquired using an Olympus DP70 digital color microscope camera mounted on an Olympus BX40 fluorescence microscope (Olympus, VIC, Australia). Random fields of view were selected for acquisition of the DAPI $(460 \mathrm{~nm})$ followed by the IL-33 $(520 \mathrm{~nm})$ channel. Within each experimental repeat, exposure times were kept constant. For image analysis, IL-33 fluorescence was first converted to a gray-scale image for the measurement of mean gray intensity using Adobe Photoshop CS3 (Adobe). The number of DAPIstained nuclei per image were then automatically counted using ImageJ software (http://rsbweb.nih.gov/ij/). An arbitrary unit of fluorescence intensity per cell was then calculated for each image and pooled for each experimental group. Intensities were then normalized to the indicated control groups for statistical analysis.

\section{RNA Extraction and Analysis by Real-Time $q R T$-PCR}

An RNeasy Fibrous Tissue kit (Qiagen 74704, Valencia, $\mathrm{CA}$ ) and RNeasy mini kit (Qiagen 74104) were used according to the manufacturers instructions to extract total RNA from skin and cultured cells, respectively. Details of the methods used have been described by us previously. ${ }^{44}$ The forward (5'-AACAGGCCTTCTTCGTCCTT- $\left.3^{\prime}\right)$ and reverse (5'-GAACGCACAGGCGTTTTACT-3') primers for IL-33 were designed using Primer $3^{45}$ and verified using a nucleotide BLAST (National Center for Biotechnology Information) search of total gene specificity. Four housekeeping genes [GAPDH, 18s, hypoxanthine phosphoribosyltransferase (HPRT), and ubiquitin] were tested. The gene 18s was not suitable, as it was found to be differentially regulated by UV in the skin. GAPDH (Fwd 5'-CCACCATGGAGAAGGCTGGGGCTC3'; Rev 5'-AGTGATGGCATGGACTGTGGTCAT-3') and HPRT (Fwd 5'-CTTTGCTGACCTGCTGGATT-3'; Rev 5'TATGTCCCCCGTTGACTGAT-3') were chosen for UVirradiated skin and cell lines, respectively, as these were the most abundantly and reliably expressed housekeeping genes. Real-time QRT-PCR using $2 \times$ platinum SYBR Green qPCR SuperMix-UDB (Invitrogen, Carlsbad, CA) was performed on a Rotor-Gene RG-6000 PCR machine. Cycle threshold $\left(\mathrm{C}_{\mathrm{T}}\right)$ values for IL-33 were normalized to GAPDH or HPRT and analyzed with Rotor-Gene 6.0 software (Corbett Research, NSW, Australia), as we have previously described. ${ }^{42}$

\section{Contact Hypersensitivity Response and Anti-IL-33 Treatment}

In addition to groups of UV-exposed mice, three other groups of mice were given three daily i.p. injections of recombinant IL-33 (0 $\mu \mathrm{g}, 0.1 \mu \mathrm{g}$, or $1 \mu \mathrm{g}$ in $200 \mu \mathrm{L}$ PBS; PeproTech, Rocky Hill, NJ). Mice were then immunized 24 hours later on the shaved, nonirradiated abdominal skin with $30 \mu \mathrm{L}$ of the chemical hapten 2,4-dinitro-1fluorobenzene (DNFB; 0.5\% v/v in 4:1 acetone:olive oil; Sigma-Aldrich, St. Louis, MO). Five days later, the ears of the mice were challenged with $15 \mu \mathrm{L}$ DNFB $(0.25 \% \mathrm{v} / \mathrm{v}$ in the same diluent) per ear, applied evenly to the dorsal and ventral surfaces. Each experiment contained a nonimmunized, challenged-only irritant control group. Increases in ear thickness were calculated using measurements taken immediately before, 24, 48, and 72 hours subsequent to DNFB challenge.

To determine whether UV-induced IL-33 is involved in UV-induced immune suppression, groups of mice were intradermally injected with $6 \mu \mathrm{g}$ goat IgG or goat antimouse IL-33 (AF3626; R\&D Systems) administered as $4 \times 25 \mu \mathrm{L}$ individual injections into the back skin. Immediately after this treatment, mice were exposed to 80 $\mathrm{kJ} / \mathrm{m}^{2} \mathrm{UV}$. The anti-IL-33 and control injections were repeated 6 and 24 hours after UV exposure. Three days after UV, mice were immunized to DNFB for contact hypersensitivity (CHS), as described above.

\section{Statistics and Data Analysis}

The rlL-33 CHS experiments contained three mice per group and were repeated twice, whereas each anti-IL-33 $\mathrm{CHS}$ experiment contained five mice per group. The mean change in ear thickness was calculated for each animals ear in each group. The ability of the anti-IL-33 treatment to prevent UV-induced immunosuppression over time was calculated for each treatment group and 
analyzed using a two-way repeated measures analysis of variance followed by a Bonferroni multiple comparison test of each individual time point. Statistical analysis of absolute ear thickness measurements was by a one-way analysis of variance followed by a Bonferroni after test of selected groups (GraphPad Prism 5 Software, version $5.0 \mathrm{c})$. For real-time qRT-PCR experiments analyzing in vivo murine IL-33 mRNA levels, values were calculated from back skin samples isolated from 10 individual mice exposed to $80 \mathrm{~kJ} / \mathrm{m}^{2}$ UV ( $n=3$ mice for the lower 36.5$\mathrm{kJ} / \mathrm{m}^{2}$ UV dose). Changes in IL-33 mRNA levels over time were statistically compared using a one-way analysis of variance followed by Dunnett's after test with the nonirradiated group serving as the control. Differences in IL-33 mRNA levels with respect to UV dose were compared by linear regression analysis. Statistical analysis of IL-33 fluorescence intensity induced by UV in primary human skin cells and murine skin cell lines was performed by a two-tailed, unpaired Student's t-test. Similarly, IL-33 mRNA and fluorescence intensity in murine tumor cell lines were analyze by a two-tailed, unpaired Student's $t$-test. The ability of platelet activating factor (PAF) or cis-UCA to induce IL-33 in murine fibroblasts as well as the effect of IL-33 on in vitro tumor cell growth was assessed statistically by a one-way analysis of variance followed by a Bonferroni's multiple post test comparing all groups.

\section{Results}

\section{Exposure of the Skin to Inflammatory Doses of UV Radiation Induces IL-33 Expression}

Groups of C57BL/6 mice were exposed to one of two ssUV doses. As can be seen in Figure 1A, inflammatory $\left(80 \mathrm{~kJ} / \mathrm{m}^{2}\right)$, but not lower subinflammatory $\left(36.5 \mathrm{~kJ} / \mathrm{m}^{2}\right)$, doses of ssUV significantly upregulated IL-33 mRNA expression in the skin, as determined by qRT-PCR. A linear regression analysis comparing the two UV doses showed that there was a significant difference between the high $\left(80-\mathrm{kJ} / \mathrm{m}^{2}\right)$ and low $\left(36.5-\mathrm{kJ} / \mathrm{m}^{2}\right)$ UV $(P=$ 0.0055). We also determined the kinetics of IL-33 upregulation in SSUV-exposed skin and found that although no increase in IL-33 message was observed at $2,4,10$, or 15 hours after $80 \mathrm{~kJ} / \mathrm{m}^{2}$ ssUV (data not shown), there was a significant upregulation of IL-33 mRNA by 24 and 72 hours after exposure to this dose of ssUV (Figure 1A). Next, we confirmed by immunofluorescence that inflammatory doses of ssUV upregulated IL-33 protein in the skin (Figure 1B). Although no IL-33 protein was detected in control nonirradiated murine skin, by 24 hours IL-33+ ${ }^{+}$cells were readily detectable in both the epidermis and dermis. This pattern of IL-33 expression was maintained and enhanced at 72 hours after ssUV exposure.

Because of its well-known immune modulating properties, we studied the effects of IL-33 on the induction of Th1 immune responses. The CHS response is a convenient and reliable model of Th1-immunity, and although UVB is known to suppress the $\mathrm{CHS}$ response
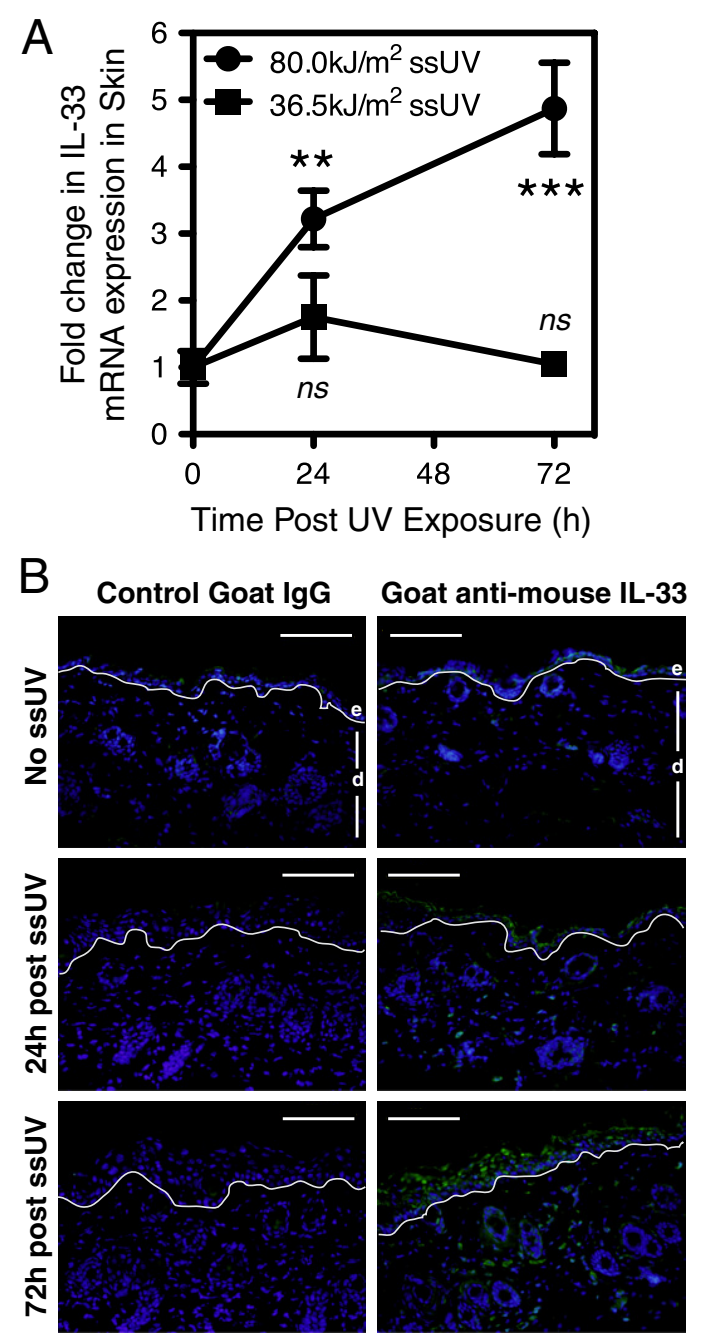

Figure 1. Exposure of the skin to inflammatory doses of UV increases IL-33 expression at both the mRNA and protein level. A: Groups of $\mathrm{C} 57 \mathrm{BL} / 6$ mice were exposed to subinflammatory $\left(36.5 \mathrm{~kJ} / \mathrm{m}^{2} ; n=3\right)$ or greater, inflammatory $\left(80 \mathrm{~kJ} / \mathrm{m}^{2} ; n=10\right)$ doses of solar simulated UV radiation (ssUV). Whole irradiated skin was isolated at 0 (nonirradiated age-matched control groups), 24 and 72 hours after UV exposure and mRNA isolated and analyzed by real-time qRT-PCR. ${ }^{* *} P<0.01,{ }^{* * * *} P<0.001$, one-way analysis of variance with Dunnett's post test. B: Whole frozen $7-\mu \mathrm{m}$ skin sections from control nonirradiated mice or mice exposed to $80 \mathrm{~kJ} / \mathrm{m}^{2}$ UV for 24 hours or 72 hours earlier were labeled with antibodies to mouse IL-33 (green). DAPI (blue) was used to identify nuclei. The white line highlights the junction between the epidermis (e) and dermis (d). Control was a control goat IgG. IL-33 protein (green) was expressed in both the epidermis and dermis of UV-exposed mice, Scale bar $=100 \mu \mathrm{m}$.

in mice ${ }^{18}$ and in humans, ${ }^{46}$ the effect of IL-33 on CHS responses is not known. To investigate this, groups of mice were injected with two different doses of recombinant IL-33. As can be seen in Figure 2A, as with exposure to ssUV, treatment of mice with IL-33 significantly suppressed induction of the $\mathrm{CHS}$ response. To determine whether UV-induced IL-33 was responsible for mediating UV-induced immunosuppression, groups of mice were treated intradermally with anti-IL-33 neutralizing antibodies and exposed to an immunosuppressive dose of UV. As can be seen in Figure 2, B and $\mathrm{C}$, neutralizing UV-induced IL-33 in this way significantly prevented UV-induced suppression of the $\mathrm{CHS}$ response. 
A

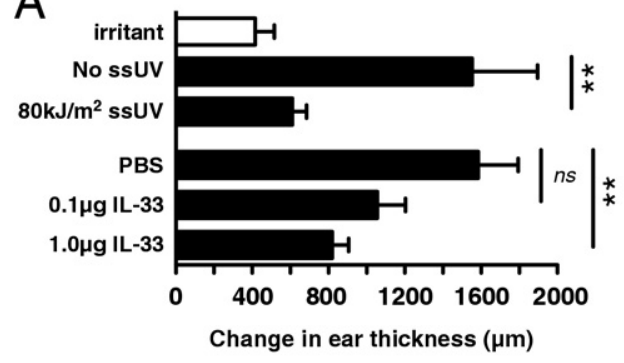

B
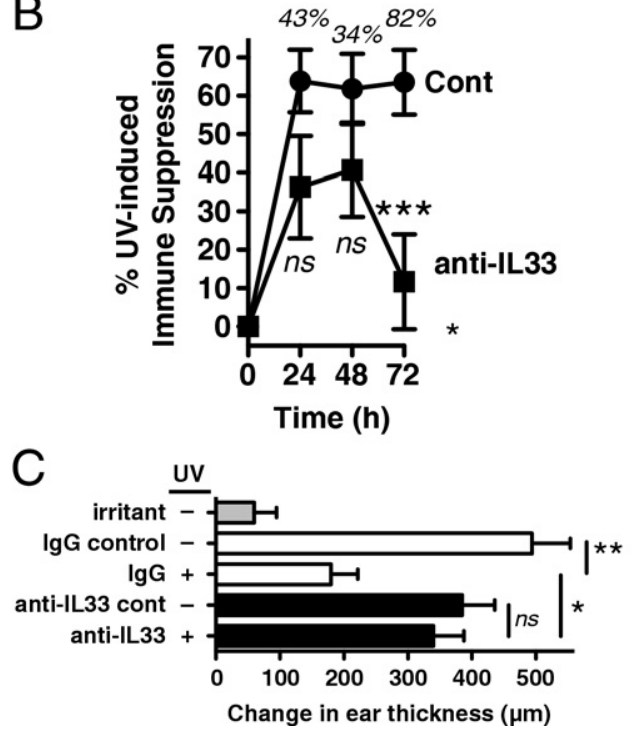

Figure 2. Injecting IL-33 suppresses, whereas blocking IL-33 inhibits, UVinduced suppression of Th1-mediated CHS responses. A: Groups of three mice were treated with three daily i.p. injections of either $0.1 \mu \mathrm{g}$ or $1.0 \mu \mathrm{g}$ of recombinant murine IL-33. Control groups consisted of PBS-injected mice as well as noninjected, nonirradiated mice, challenged-only mice (irritant control), and mice that received $80 \mathrm{~kJ} / \mathrm{m}^{2}$ ssUV 3 days earlier. All groups were then sensitized to the contact allergen DNFB and subjected to a contact hypersensitivity response (CHS). The 24 hour post-challenge results are presented as the mean ear swelling response + SEM, $n=6$ per group (pooled from two repeats); ${ }^{* *} P<0.01$ by one-way analysis of variance and Bonferroni post-test. $\mathbf{B}$ and $\mathbf{C}$ : Groups of five mice were treated in the back with four intradermal injections of control or $6 \mu \mathrm{g}$ anti-IL-33 neutralizing antibody. This treatment was performed at 0,6 , and 24 hours after exposure to $80 \mathrm{~kJ} / \mathrm{m}^{2}$ ssUV. Three days after the UV exposure, mice were subjected to CHS. B: Results are presented as the ability of the treatment to prevent UV-induced immunosuppression. Mean \pm SEM for control (circles) or antiIL-33-treated groups (squares) are shown from 0 to 72 hours after DNFB challenge. ${ }^{*} P<0.05$ by two-way repeated-measures analysis of variance; ${ }_{* * * *} P<0.001$ by Bonferroni multiple comparison. Italicized numbers refer to the percent inhibition of UV-induced immunosuppression afforded by antiIL-33 treatment. C: Absolute 72-hour ear thickness measurements of the various groups are presented for comparison. Mean + SEM are shown. ${ }^{*} P<$ 0.05 and ${ }^{* * *} P<0.0001$ by one-way analysis of variance and Bonferroni's multiple-comparison post-test.

To determine the cellular source of the ssUV-induced IL-33, we dual-labeled ssUV-exposed murine skin with antibodies to IL-33 and CD45, a marker for cells of bone marrow origin. No $\mathrm{IL}-33^{+} \mathrm{CD} 45^{+}$double-positive cells were seen at any time point in any section analyzed (Figure 3A). Furthermore, IL-33 ${ }^{+}$cells were negative for CD11b and major histocompatibility complex (MHC) class II (data not shown). Exposure of the immortalized murine keratinocyte cell line PAM212 or murine embryonic fibroblasts (MEF) to ssUV in vitro (Figure 3B) showed that IL-33 was induced in both keratinocytes and fibro- blasts. The cellular localization observed after exposure to ssUV revealed IL-33 expression in both the nucleus and cytoplasm. Quantitative image analysis confirmed that SsUV significantly induced IL-33 in these two skin cell types (Figure 3C).

Next, we investigated whether ssUV could also induce IL-33 expression in human skin. Consistent with other studies, ${ }^{22,35} \mathrm{IL}-33$ was constitutively expressed in the epithelial layers of human skin (Figure 4A). However, similar to our observations in murine skin, ssUV upregu-
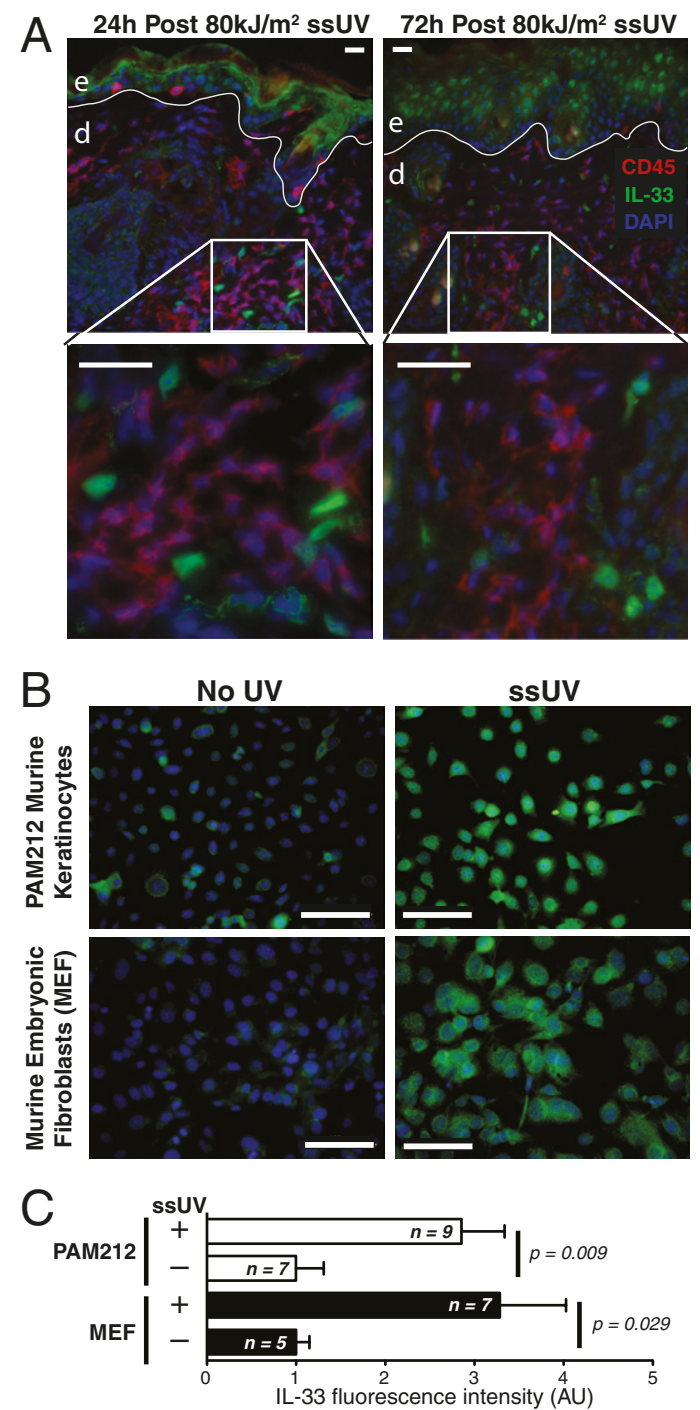

Figure 3. UV radiation upregulates IL-33 in both murine keratinocytes and dermal fibroblasts. A: Whole frozen $7-\mu \mathrm{m}$ skin sections from mice exposed to $80 \mathrm{~kJ} / \mathrm{m}^{2}$ ssUV 24 hours or 72 hours earlier were simultaneously labeled with antibodies to mouse IL-33 (green) and CD45 (red). DAPI (blue) was used to identify nuclei. The white line highlights the junction between the epidermis (e) and dermis (d). The bottom panels shows a high-power magnification of dermal cells from those depicted in the top panels. Scale bar (all images) $=20 \mu \mathrm{m}$. B: The PAM 212 murine keratinocyte cell line or fibroblasts cultured from mouse embryos [murine embryonic fibroblasts (MEF)] at $80 \%$ confluence were exposed to $60 \mathrm{~kJ} / \mathrm{m}^{2}$ ssUV in vitro. Twenty-four hours later, the cells were fixed and stained for IL-33. Control, nonirradiated cells stained for IL-33 are also shown. C: Quantitative image analysis of IL-33 expression. Fluorescence intensities for each treatment and cell type were first determined on a per cell basis before normalizing the level of expression to the control, nonirradiated samples. Mean + SEM are shown. $P<0.05$ by a unpaired two-tailed Student's $t$-test was considered statistically significant. 
lated this epidermal expression and induced IL-33 within cells of the dermis (Figure 4A). To identify the human cell types induced to express IL-33 we exposed normal human keratinocytes (NHK) and fibroblasts (NHF) from another adult donor to SsUV in vitro (Figure 4B). Similar to the expression observed in murine cells (Figure 3B), IL-33 was expressed in both the nucleus and cytoplasm of primary human cells exposed to ssUV (Figure 4B). Quantitative immunofluorescent image analysis of IL-33 protein expression in these cells confirmed that SSUV induced significant IL-33 expression in both human keratinocytes and fibroblasts (Figure $4 \mathrm{C}$ ). Finally, primary fibroblasts obtained from three additional human donors were exposed to ssUV. Two of three of these primary human cells showed a statistically significant $(P<0.01)$ increase in IL-33 protein expression (Figure 4D). Fibroblasts from the third donor also showed an increase in IL-33 expression, although this did not reach statistical significance $(P>0.05)$.

\section{Epithelial-Derived UV-Induced Skin Tumors That Evade Immunological Destruction Express Significantly Higher Levels of IL-33}

LK-2 is a squamous cell carcinoma (SCC) cell line that will initially grow when injected into syngeneic $\mathrm{C} 3 \mathrm{H} / \mathrm{HeN}$ mice from which the cells were derived, before being recognized by the immune system and undergoing immune-mediated rejection. In contrast, 13-1 is an SCC cell line that continues to progress when injected into syngeneic $\mathrm{C} 3 \mathrm{H} / \mathrm{HeN}$ mice. ${ }^{41}$ Because the epithelial layers of both murine and human skin expressed significant amounts of IL-33 after UV exposure, we investigated by qRT-PCR and immunofluorescence whether these UVinduced SCC express IL-33. As can be seen in Figure 5A, cultured LK-2 regressor tumor cells expressed little to no IL-33, whereas 13-1 progressor cells expressed significant amounts. This expression did not require exposure to sSUV and was constitutive. Comparative quantitative analysis of IL-33 expression confirmed that tumor cells that evade immunological destruction express significantly higher levels of both IL-33 protein (Figure 5B) and mRNA (Figure 5C). Similar to that observed in murine (Figure 3) and human (Figure 4B) cells after exposure to ssUV, IL-33 was expressed in both the nucleus and cytoplasm of 13-1 progressor tumor cells (Figure 5A). To determine the effect of IL-33 on tumor growth in vitro, LK-2 and 13-1 cells were cultured in the presence of various concentrations of rlL-33. As can be seen in Figure 5D, IL-33 neither enhanced nor inhibited the growth of these tumor cells. The doses of rlL-33 used in these experiments were biologically effective, as they were able to induce IL-6 and IL-13 secretion by bone marrow-derived mast cells (data not shown), consistent with what has previously been described. ${ }^{29}$

\section{UVB and PAF Induce IL-33 Expression in Skin}

Penetration of the skin by sunlight is wavelength dependent, with longer wavelengths able to penetrate deeper

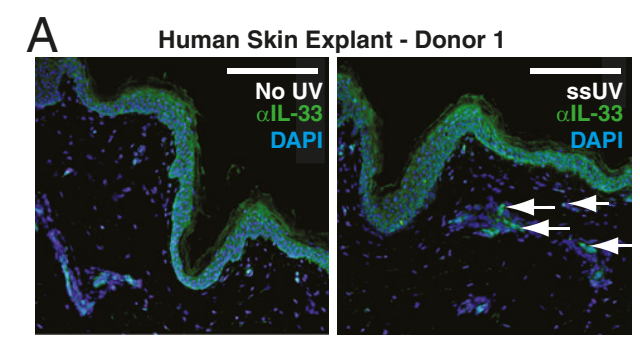

B Normal Human Keratinocytes (NHK) - Donor 2
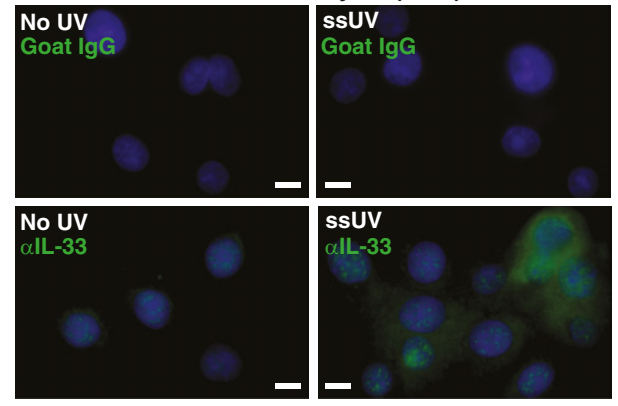

Normal Human Fibroblasts (NHF) - Donor 2
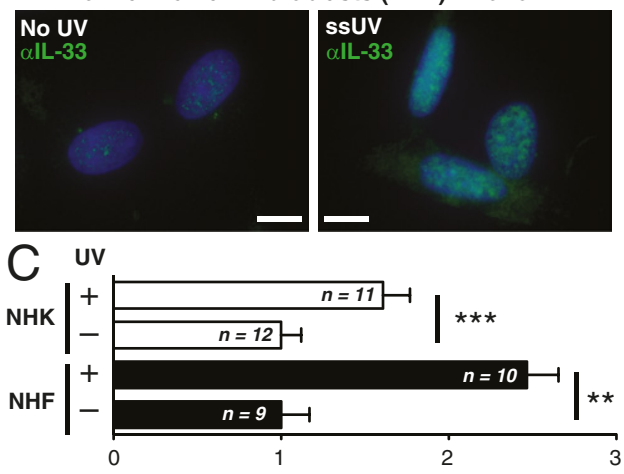

IL-33 fluorescence intensity (AU)

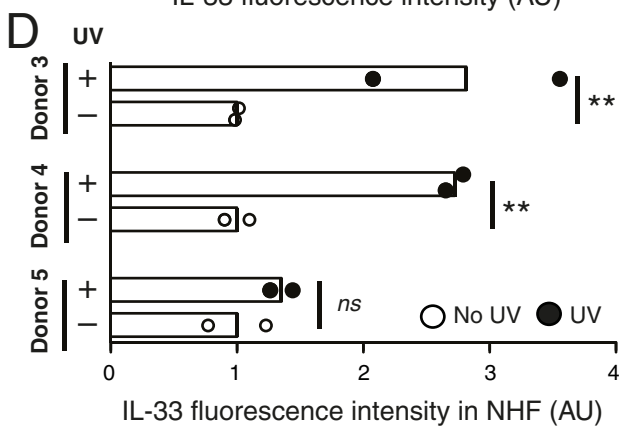

Figure 4. UV upregulates IL-33 in human skin explants and cells derived from normal human skin. A: Whole skin samples obtained from a human donor undergoing abdominal reduction surgery were either not irradiated or were exposed to $160 \mathrm{~kJ} / \mathrm{m}^{2} 24$ hours before snap freezing for processing and labeling for IL-33 (green). DAPI (blue) was used to identify nuclei. Arrows indicate the numerous IL-33-positive cells deep within the dermis. Scale bar $=200 \mu \mathrm{m}$. B: Normal human keratinocytes (NHK) or normal human fibroblasts (NHF) at $80 \%$ confluence were exposed to $60 \mathrm{~kJ} / \mathrm{m}^{2}$ ssUV in vitro. Twenty-four hours later, the cells were fixed and stained for IL-33 or control goat IgG. Control nonirradiated cells are shown in the left column. Scale bar $=10 \mu \mathrm{m}$. C and D: Quantitative image analysis of IL-33 protein expression in NHK and NHF from one adult donor (C) and NHF from three additional human foreskin samples (D). Fluorescence intensities for each treatment and cell type were first determined on a per cell basis before normalizing the level of expression to the control nonirradiated samples. C: Mean + SEM are shown. ${ }^{* * *} P<0.01,{ }^{* * a k e} P<0.001$ by unpaired two-tailed Student's $t$-test. D: Bars indicate overall mean IL-33 expression. Circles indicate mean IL-33 expression (more than two fields of view analyzed) in separate independent fibroblast cultures of nonirradiated (open circles) or $60-\mathrm{kJ} / \mathrm{m}^{2}$ ssUV-exposed samples (filled circles). ${ }^{* *} P<0.01$, by unpaired two-tailed Student's $t$-test. 
into the skin. ${ }^{47}$ UVA (320 to $400 \mathrm{~nm}$ ) therefore penetrates more deeply into the skin, with substantial amounts reaching as far down as the dermis and subcutaneous tissue. In contrast, only a small percentage of total UVB (290 to $320 \mathrm{~nm}$ ) is able to penetrate deeper than the epidermis, and, as such, UVB affects mainly epidermal

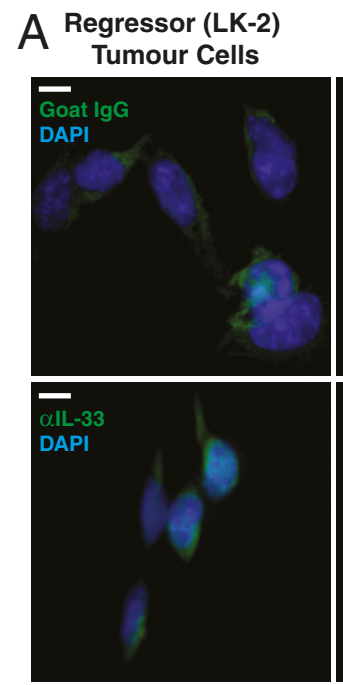

Progressor (13-1)

Tumour Cells

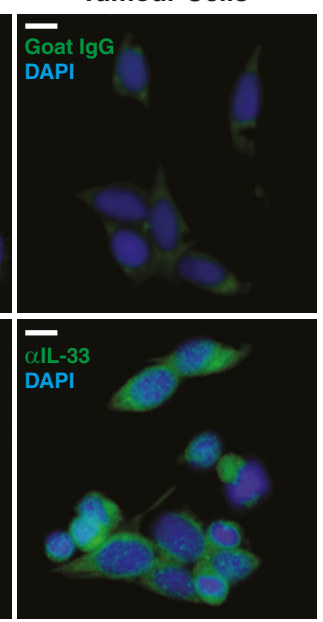

\section{B}

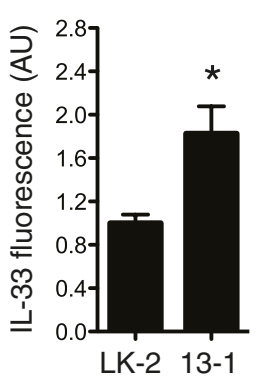

C
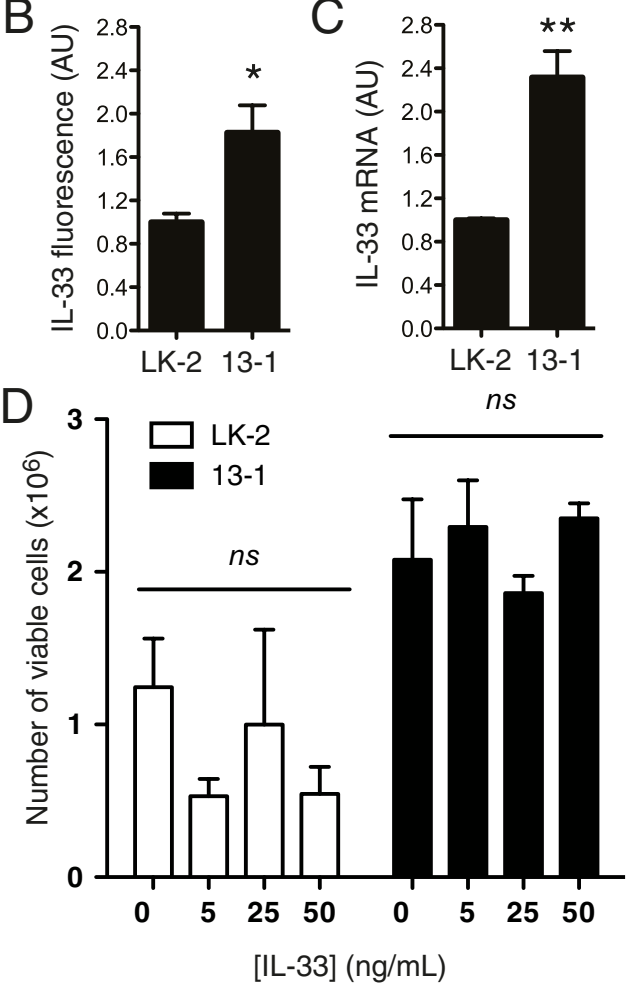

Figure 5. Progressor UV-induced skin tumors express significantly more immune suppressive IL-33 than tumors that are recognized and destroyed by the immune system. A: Untreated, in vitro-cultured LK-2 regressor or 13-1 progressor tumor cells were fixed and stained for either control goat IgG or murine IL-33. Scale bar $=10 \mu \mathrm{m}$. B: Quantitative image analysis of IL-33 protein expression in the two tumor cell cultures normalized to the expression in LK-2 cells $\left(n=5\right.$ separate cultures for each tumor line; ${ }^{*} P=0.035$ by unpaired two-tailed Student's $t$-test). C: Real-time qRT-PCR of IL-33 mRNA normalized to the expression in LK-2 cells. Three separate cultures were used for each tumor line. ${ }^{* *} P=0.0056$ by unpaired two-tailed Student's $t$-test). D: Growth of LK-2 and 13-1 in the presence of increasing doses of recombinant murine IL-33. Mean \pm SEM from two separate cultures are shown. cells. This explains the pattern of IL-33 expression that we observed in the epidermis and UV-induced SCC cell lines. However, the results shown in Figures $1 \mathrm{~B}$ and $2 \mathrm{~A}$ using ssUV to induce IL-33 expression in both epidermal and dermal cells suggested that UVA may play a dominant role in inducing dermal IL-33. We therefore separated the solar UV spectrum into either UVA or UVB and delivered that component only to the mice to determine which wavelengths are responsible for the increase in IL-33 expression. Exposure to UVB (Figure 6B), but not UVA (Figure 6A), increased IL-33 expression in skin. Despite the poor ability of UVB to penetrate deep into the dermis, $\mathrm{IL}-33^{+}$cells were found in both the epidermis and deep within the dermis. This observation suggested that a UVB-induced, epidermally derived soluble factor must be responsible for induction of IL-33 within the dermis. A number of factors are known to affect the expression of IL-1 family members, including extracellular ATP binding to $\mathrm{P} 2 \mathrm{X}_{7}$ receptors. ${ }^{48}$ We recently showed that exposure of human skin cells to UV results in a significant depletion of intracellular ATP stores, ${ }^{49}$ and $\mathrm{P}^{2} \mathrm{X}_{7}$ receptors are abundantly expressed in both human ${ }^{50}$ and murine $^{51}$ skin. Therefore, to test whether a UV-induced soluble factor binding to $\mathrm{P} 2 \mathrm{X}_{7}$ receptors is the mechanism by which UV induces IL-33 in skin, we exposed either wild-type (Figure 6C) or $\mathrm{P}_{2} \mathrm{X}_{7}$ receptor-deficient mice (Figure $6 \mathrm{D}$ ) to an IL-33-inducing, inflammatory dose of

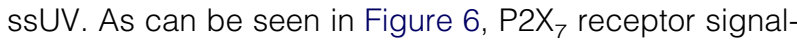
ing is not required for UV-induced IL-33 in the skin because both groups of mice showed an increase in IL-33 expression. A number of other soluble factors are released within the skin after exposure to inflammatory doses of UV, including cis-urocanic acid (cis-UCA) ${ }^{52}$ and the oxidized membrane lipid PAF. ${ }^{53}$ To determine whether cis-UCA (Figure 6F) or PAF (Figure 6G) could directly induce IL-33 expression in fibroblasts, we incubated MEFs with each of these factors for 1 hour or 4 hours. As can be seen in Figure 6, E-H, only PAF significantly upregulated IL-33 expression in these cells.

\section{Dermal Mast Cells and Skin-Infiltrating Neutrophils Associate with UV-Induced IL-33-Expressing Fibroblasts}

A number of different cell types have now been shown to respond to IL-33. However, apart from fibroblasts themselves, ${ }^{54}$ dermal mast cells are one of the only cell types to express $\mathrm{IL}-33$ receptors in resting noninflammed skin. ${ }^{22}$ Therefore, to establish the relationship between IL-33-producing cells and dermal mast cells, we duallabeled SSUV-exposed murine skin with antibodies to IL-33 and CD117, a marker highly expressed by mast cells. Although mast cells themselves have recently been shown to produce IL-33, ${ }^{55}$ no IL- $33^{+} \mathrm{CD} 117^{+}$cells were seen at any time point in any section analyzed (Figure 7 , $A$ and $B$ ); rather, $\mathrm{IL}-33^{+}$cells were found adjacent to CD $117^{+}$mast cells in almost all UV-exposed skin sections analyzed. To exclude the possibility that we were mistaking $\mathrm{CD} 117^{+}$mast cells for melanocytes expressing low levels of CD117, we stained the IL-33-labeled 

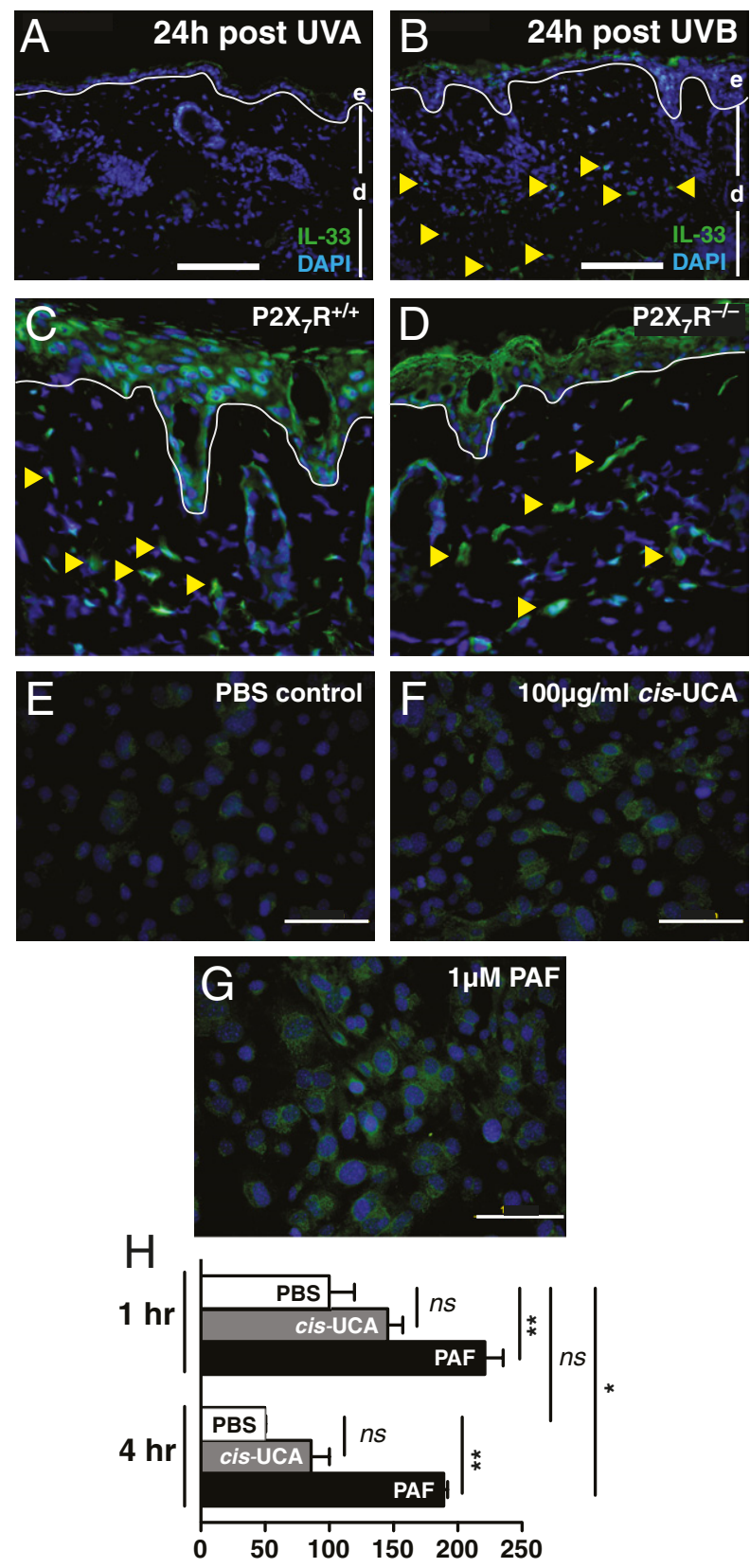

Relative IL-33 Expression (\% of cont)

Figure 6. UVB and PAF, but not cis-UCA or signals working via P2X receptors upregulates $\mathrm{IL}-33$ in the skin. Mice were exposed to either the (A) UVA or (B) UVB components of $80 \mathrm{~kJ} / \mathrm{m}^{2} \operatorname{ssUV}\left(74.25 \mathrm{~kJ} / \mathrm{m}^{2}\right.$ UVA only or $5.75 \mathrm{~kJ} / \mathrm{m}^{2}$ UVB only). Arrowheads indicate IL-33-positive cells within the dermis. Frozen skin sections were then labeled for IL-33 as described for Figure 1B. The white line highlights the junction between the epidermis (e) and dermis (d). Scale bar $=100 \mu \mathrm{m}$. Whole frozen $7-\mu \mathrm{m}$ skin sections from $\mathrm{P}_{2} \mathrm{X}_{7}$ receptor-expressing wild-type $(\mathbf{C})$ or $\mathrm{P} 2 \mathrm{X}_{7}$ receptor-deficient (D) mice exposed to $80 \mathrm{~kJ} / \mathrm{m}^{2}$ UV 72 hours earlier were labeled with antibodies to mouse IL-33 (green). In all images (A-G), DAPI (blue) was used to identify nuclei. The white line highlights the dermalepidermal junction. Arrowheads point to IL-33-positive cells deep within the dermis of both strains of mice. E-G: Murine embryonic fibroblasts at $80 \%$ confluence were cultured with control PBS (E), $100 \mu \mathrm{g} / \mathrm{mL}$ cis-UCA (F), or $1 \mu \mathrm{mol} / \mathrm{L} \operatorname{PAF}(\mathbf{G})$ in vitro. The images displayed were taken after 1 hour of exposure to the respective reagents, at which point the cells were fixed and stained for IL-33. Scale bar $=100 \mu \mathrm{m}$. $\mathbf{H}$ : Quantitative image analysis of IL-33 expression was performed on the cell cultures as described for Figure 2C ( $n=2$ for each treatment group and time point) and presented as a percentage of the 1-hour control group. Mean \pm SEM are shown, with ${ }^{*} P<0.05,{ }^{* * *} P<0.01$ by one-way analysis of variance and Bonferroni's multiple comparison post-test. skin sections with toluidine blue (Figure 7C), which specifically identifies the acid-fast granules in mast cells. As can be seen in this lower-powered photomicrograph, numerous $\mathrm{IL}_{-} 33^{+}$cells were found adjacent to and surrounding dermal mast cells.

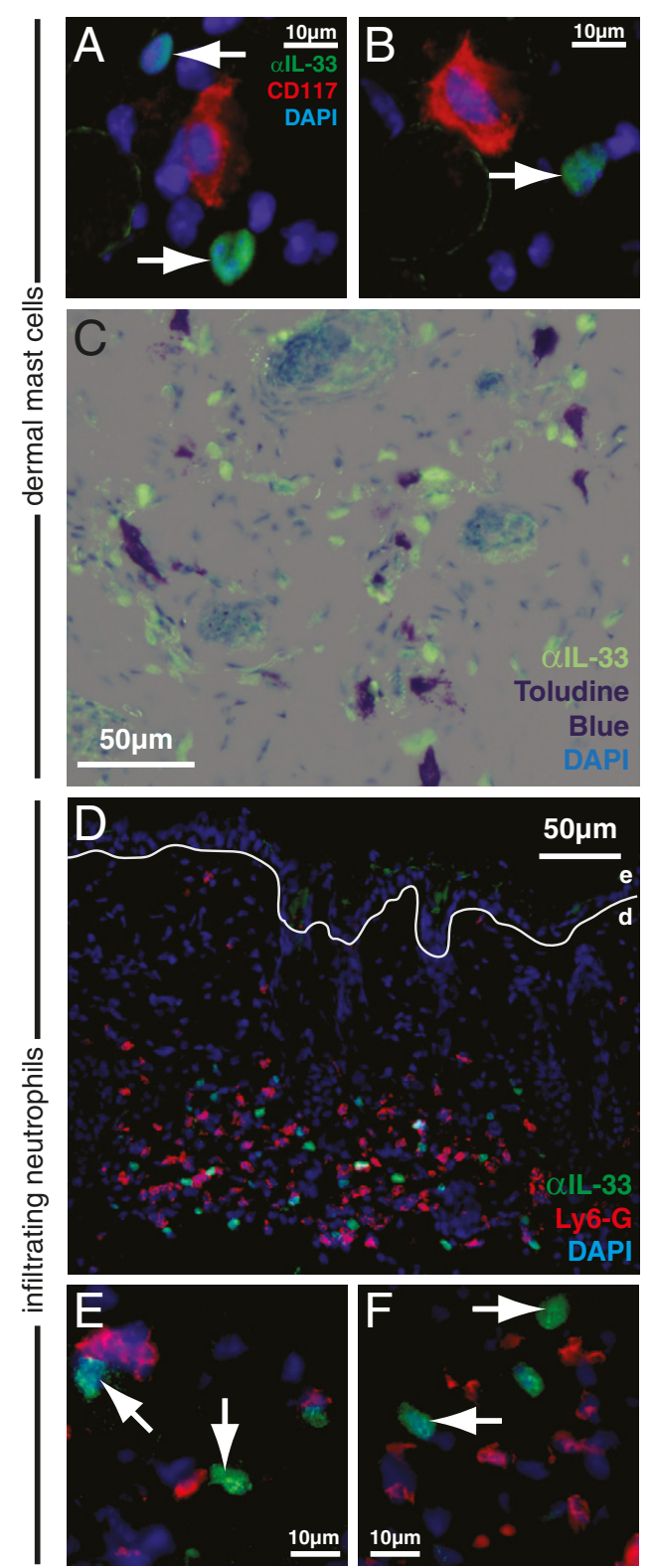

Figure 7. Dermal mast cells and neutrophils associate with IL-33-expressing cells after exposure to UV. A and B: Whole frozen $7-\mu \mathrm{m}$ skin sections from mice exposed to $80 \mathrm{~kJ} / \mathrm{m}^{2}$ ssUV 72 hours earlier were simultaneously labeled with antibodies to mouse IL-33 (green) and CD117 (red; to identify mast cells). In all images, DAPI (blue) was used to identify nuclei. Two representative dermal images are shown where arrows point to IL-33-expressing cells in close proximity to CD $117+$ mast cells. C: Digital image overlay of the same UV-exposed dermal section labeled and photographed first for IL-33 (green), followed by toluidine blue labeling of mast cells (purple-stained granules). D: Low-power photomicrograph of UV-exposed skin sections isolated from mice exposed to $80 \mathrm{~kJ} / \mathrm{m}^{2}$ ssUV 24 hours earlier labeled simultaneously for murine IL-33 (green) and Ly6-G (red; to specifically identify neutrophils). The white line highlights the junction between the epidermis (e) and dermis (d). E and F: Two representative high-power images of IL-33-stained dermal cells (green and indicated by arrows), together with Ly6-G-labeled neutrophils (numerous red cells). No Ly6-Gstained cells were found in any control nonirradiated skin sections. 
The results from our CD45-labeling experiments showed that, after exposure to UV, there is a large infiltration of inflammatory cells (Figure 3A). Although some of the CD45-labeled cells will be resident mast cells (Figure $7 \mathrm{~A}-\mathrm{C}$ ), to identify other cell types that might be responsible for the increase in $\mathrm{CD} 45^{+}$cells, we dual-labeled ssUV-exposed murine skin with antibodies to IL-33 and Ly-6G, a neutrophil-specific marker. Consistent with previous reports in UVB-exposed human skin, ${ }^{56}$ a large number of Ly-6G-expressing neutrophils were found in ssUV-exposed murine skin (Figure 7D). These cells were found deep in the dermis in contact with, and surrounded by, numerous IL-33 ${ }^{+}$cells (Figure 7, E and F).

\section{Discussion}

Our data show that inflammatory doses of UVB significantly upregulates IL-33 mRNA and protein in the skin of both mice and humans, with mRNA being increased 24 hours after ssUV exposure. This pattern of increased IL-33 mRNA and protein expression was maintained and enhanced at 72 hours after ssUV exposure. Environmentally exposed epithelial cells such as those in human skin express $\mathrm{IL}-33,{ }^{35}$ and although $\mathrm{IL}-33$ mRNA has been found in human fibroblasts, ${ }^{22} \mathrm{IL}-33$ protein is not expressed by resting human dermal fibroblasts. ${ }^{35,57}$ Our data confirm these observations, as no IL-33 protein was seen in the dermis of naive, nonirradiated murine skin samples. However, exposure to a physiologically relevant dose of SSUV induced the expression of IL-33 in both epidermal and dermal layers. Exposure of murine cell lines and primary human cells to SSUV in vitro confirmed that both epidermal keratinocytes and dermal fibroblasts produce IL-33 after ssUV exposure. Although this ssUV-induced IL-33 was observed in both the nucleus and cytoplasm of exposed cells, more pronounced nuclear IL-33 staining was seen in UV-exposed fibroblasts (Figure 4B). The role that UV-induced IL-33 plays in the nucleus is unclear. IL-33 has been shown to function as either a chromatin-associated nuclear factor ${ }^{58}$ or a classical cytokine secreted after cellular stress or destruction. ${ }^{59}$ In this way, IL-33 is proposed to act as a novel alarmin produced in response to trauma or infection. ${ }^{35,37}$ As we have shown previously, the lower $\left(36.5-\mathrm{kJ} / \mathrm{m}^{2}\right)$ dose of ssUV is not high enough to cause significant inflammation in these mice (ie, it is subinflammatory). ${ }^{18}$ In contrast, the higher $\left(80 \mathrm{~kJ} / \mathrm{m}^{2}\right)$ dose of ssUV is approximately twice the minimum dose of SsUV required to cause significant skin thickening and cell damage. Our results therefore identify and support a role for IL-33 as an early danger signal produced in response to inflammationinducing UV radiation. Although this is considered an inflammatory dose, it is the equivalent of approximately 20 minutes of exposure to midday summer sunlight in Sydney, Australia. Although not considered high by the general population, these doses are sufficient to cause a mild sunburn reaction in most individuals. It is therefore a physiologically relevant dose of UV that humans routinely receive during recreational activities.

To determine what role UV-induced IL-33 might play in skin cancer, we analyzed two UV-induced SCC cell lines that have opposing in vivo growth characteristics. ${ }^{41}$ Our study revealed that UV-induced progressor SCC express significantly higher constitutive IL-33 levels than regressor SCC. IL-33 has been shown to prevent apoptosis in cardiomyocytes $^{60}$ and to promote the survival and viability of mast cells ${ }^{61}$ as well as eosinophils. ${ }^{62}$ More recently, IL-33 was shown to induce extracellular signal-regulated kinase (ERK) expression in lung epithelial cells. ${ }^{63}$ UVB activation of ERK not only induces proliferation of human keratinocytes, $^{64}$ it promotes keratinocyte survival by down-regulating the tumor suppressor PTEN (phosphatase and tensin homolog deleted on chromosome 10). ${ }^{65}$ These previous studies suggest that IL-33 may provide a growth advantage to UV-induced epithelial-derived tumor cells. However, we did not observe enhanced tumor growth when these cells were grown in the presence of biologically active doses of rlL-33 (Figure 5D).

Exposure to UVB suppresses CD4 ${ }^{+}$type 1-helper (Th1) $\mathrm{T}$ cell activation. ${ }^{11,66}$ Characterized by their production of IFN $\gamma$ and support of $\mathrm{CD}^{+}$cytotoxic $\mathrm{T}$ cell activity, Th1-immune responses are considered the most effective for both preventing tumor formation and controlling established tumor growth. ${ }^{67}$ Suppression of Th1-immune responses therefore makes a significant contribution to the ability of UVB to cause skin cancer. ${ }^{68} \mathrm{IL}-33$ suppressed the induction of the Th1-mediated $\mathrm{CHS}$ response (Figure 2A); and because LK-2 regressor tumors grow progressively in athymic nude mice, ${ }^{69}$ our data therefore suggests that production of IL-33 by tumor cells may provide a novel pathway for evading Th1-mediated immunological destruction.

The solar UV spectrum is made up of a combination of UVA ( $95 \%$ ) and UVB ( $5 \%$ ) wavelengths, both of which make significant contributions to skin cancer development by damaging DNA ${ }^{70,71}$ and suppressing adaptive immune responses. ${ }^{18,46,72}$ The presence of IL-33-producing cells deep within the dermis of UVB but not UVAexposed skin suggested that a UVB-induced soluble factor was responsible. PAF is an oxidized lipid released from cell membranes exposed to UVB. ${ }^{73}$ This rapid production and release of PAF leads to suppression of adaptive immune response ${ }^{10}$ and contributes to the development of UV-induced skin cancer. ${ }^{74}$ PAF mediates some of these biological effects by modulating the production of cytokines in target cells. For example, keratinocytes produce IL-10, ${ }^{10}$ whereas fibroblasts secrete IL-6 and $\mathrm{IL}-8,{ }^{75}$ in response to PAF stimulation. Our results reveal for the first time that exposure to either ssUV or PAF activates fibroblasts to produce IL-33.

Fibroblast expression of the IL-33 receptor ST2 ${ }^{54}$ suggests that UV-induced IL-33 may act locally in an autocrine manner. Operating in this way, IL-33 produced by activated dermal fibroblasts/myofibroblasts has been implicated in the fibrotic pathology associated with systemic sclerosis. ${ }^{57}$ Alternatively, IL-33 could modulate the function of adjacent skin cells in a paracrine manner. Although dermal mast cells themselves did not produce 
IL-33 after UVB exposure, their close proximity to IL-33producing fibroblasts, together with their abundant expression of ST2 implies that they are likely to be among the first cells to respond to UVB-induced IL-33. Highlighting the importance of our results is evidence that stimulating bone marrow-derived murine mast cells with IL-33 causes the release of a number of immune-modulating cytokines, including IL-10. Mast cell-derived IL-10 is required to maintain skin homeostasis after exposure to excessive amounts of UVB. ${ }^{76}$ In addition, UV-induced IL-10 plays a key role in skin cancer development, as IL-10-deficient mice are completely protected from developing skin tumors after long-term exposure to carcinogenic UV. ${ }^{77}$ More recently, UV-induced vitamin D3 was shown to be one trigger for IL-10 production by dermal mast cells. ${ }^{78}$ Our study suggests that UV-induced IL-33 may also promote skin homeostasis and may contribute to skin cancer development by activating mast cell production of IL-10.

We discovered that newly recruited Ly6-G $\mathrm{G}^{+}$neutrophils home to, and closely associate with, the IL-33producing cells deep within the dermis of UV-exposed skin. Neutrophil infiltration is a very early cellular event occurring in response to sunlight, with significant numbers first appearing in human dermis within 10 hours and reaching a maximum by 24 hours after UVB exposure. ${ }^{56}$ The majority of these UV-recruited neutrophils home to the dermis ${ }^{56}$ where they mediate immune suppression via IL-4 and IL-10 production. ${ }^{56,79}$ Between days 3 and 5 after UV exposure, CD11 $\mathrm{b}^{+} \mathrm{IL}-10$-producing macrophages start to appear. ${ }^{80}$ Macrophage phenotype can be altered by IL-33 ${ }^{81}$ suggesting that UV-induced IL-33 may also affect macrophage function, although further studies are required to determine whether this is the case. The significance of neutrophil homing to IL-33 producing dermal cells has only recently become apparent, when it was demonstrated that IL-33 enhances the expression of ST2 on neutrophils, allowing them to directly respond to IL-33 signals in tissues. This IL-33-mediated event enabled the neutrophils to home to sites of infection and prevent sepsis. ${ }^{28}$ As we were unable to detect a UV-induced increase in systemic IL-33 levels (data not presented), and because neutrophils fail to constitutively express high levels of ST2, ${ }^{25}$ it is unlikely that UV-induced IL-33 is directly responsible for the infiltration of neutrophils into UVB-exposed skin. CXCL8 (IL-8) is a potent neutrophil chemoattractant produced by UV-irradiated human epidermal keratinocytes ${ }^{82}$ and Langerhans cells. ${ }^{83}$ However, we did not observe any neutrophils in association with IL-33-producing epidermal cells, implying a dermal origin for neutrophil chemoattractants. Although the dermal cells responsible for recruiting neutrophils following UVB exposure are not known, studies using mast cell deficient mice show that mast cells are critical cellular intermediaries required for the recruitment of neutrophils to sites of inflammation. ${ }^{84}$ While direct exposure of cord blood derived mast cells to UVB in vitro causes CXCL8 production in these cells, ${ }^{85}$ this is unlikely to be the primary mechanism by which dermal mast cells produce CXCL8 after UV exposure in vivo; rather, we hypothesize that UVB-induced PAF stimulates IL-33 pro- duction in fibroblasts that then acts either in an autocrine manner ${ }^{86}$ or on neighboring dermal mast cells ${ }^{23}$ to induce expression of neutrophil chemoattractants such as CXCL8. In this way, UV-induced IL-33 acts as a novel endogenous danger signal mediating the recruitment of innate immune cells to sites of infection or cellular damage.

In conclusion, IL-33 is a novel endogenous alarmin produced in response to inflammation and tissue damage. ${ }^{35,37}$ The pattern of IL-33 expression in various cells and tissues has led to the suggestion that IL-33 expression in peripheral tissues such as the skin must be modulated by external environmental cues. ${ }^{35}$ We have identified UVB in sunlight as one of these environmental cues. IL-33 was produced in the skin in response to physiologically relevant, environmentally acquired UVB radiation that, when blocked with neutralizing antibodies, prevented UV-induced immunosuppression. The dermal assemblage of IL-33-producing fibroblasts, mast cells, and neutrophils that we observed shortly after exposure to UV has important implications for the maintenance of skin homeostasis, immune suppression, and promotion of innate immune mechanisms. The expression of IL-33 by UV-induced progressing SCC tumor cells suggests that IL-33 may also play a role in tumor growth and immune evasion. IL-33 induced by exposure to inflammatory UVB may therefore be an important mechanism to minimize tissue damage and prevent infection. In the long term, however, there may be ramifications for the development of UV-induced skin cancers.

\section{Acknowledgments}

We thank Dr. Xiao Xuan Huang for supplying normal human keratinocytes and fibroblasts, as well as Ms. Vanessa El-Achi and Mr. Quang Huang for their help in data acquisition and analysis.

\section{References}

1. Kripke ML, Fisher MS: Immunologic parameters of ultraviolet carcinogenesis. J Natl Cancer Inst 1976, 57:211-215

2. McMichael AJ, Hall AJ: Does immunosuppressive ultraviolet radiation explain the latitude gradient for multiple sclerosis? Epidemiology 1997, 8:642-645

3. Ullrich SE: Suppression of the immune response to allogeneic histocompatibility antigens by a single exposure to ultraviolet radiation. Transplantation 1986, 42:287-291

4. Singh TP, Schön MP, Wallbrecht K, Michaelis K, Rinner B, Mayer G, Schmidbauer U, Strohmaier H, Wang XJ, Wolf P: 8-methoxypsoralen plus ultraviolet $A$ therapy acts via inhibition of the IL-23/Th17 axis and induction of Foxp3+ regulatory T cells involving CTLA4 signaling in a psoriasis-like skin disorder. J Immunol 2010, 184:7257-7267

5. Silva SH, Guedes AC, Gontijo B, Ramos AM, Carmo LS, Farias LM, Nicoli JR: Influence of narrow-band UVB phototherapy on cutaneous microbiota of children with atopic dermatitis. J Eur Acad Dermatol Venereol 2006, 20:1114-1120

6. Maeda A, Schwarz A, Bullinger A, Morita A, Peritt D, Schwarz T: Experimental extracorporeal photopheresis inhibits the sensitization and effector phases of contact hypersensitivity via two mechanisms: generation of IL-10 and induction of regulatory T cells. J Immunol 2008, 181:5956-5962

7. Halliday GM, Norval M, Byrne SN, Huang XX, Wolf P: The effects of sunlight on the skin. Drug Discovery Today 2008, 5:e201-e209 
8. Gläser R, Navid F, Schuller W, Jantschitsch C, Harder J, Schröder JM, Schwarz A, Schwarz T: UV-B radiation induces the expression of antimicrobial peptides in human keratinocytes in vitro and in vivo. $J$ Allergy Clin Immunol 2009, 123:1117-1123

9. Schwarz A, Maeda A, Kernebeck K, van Steeg H, Beissert S, Schwarz $\mathrm{T}$ : Prevention of UV radiation-induced immunosuppression by IL-12 is dependent on DNA repair. J Exp Med 2005, 201:173-179

10. Walterscheid JP, Ullrich SE, Nghiem DX: Platelet-activating factor, a molecular sensor for cellular damage, activates systemic immune suppression. J Exp Med 2002, 195:171-179

11. Shreedhar V, Giese T, Sung VW, Ullrich SE: A cytokine cascade including prostaglandin E2. IL-4, and IL-10 is responsible for UVinduced systemic immune suppression. J Immunol 1998, 160:37833789

12. Hart PH, Grimbaldeston MA, Jaksic A, Tan JE, Swift GJ, Hosszu EK, Halliday GM, Finlay-Jones JJ: Ultraviolet B-induced suppression of immune responses in interleukin-4-/-mice: relationship to dermal mast cells. J Invest Dermatol 2000, 114:508-513

13. Noonan FP, Bucana C, Sauder DN, De Fabo EC: Mechanism of systemic immune suppression by UV irradiation in vivo. II. The UV effects on number and morphology of epidermal Langerhans cells and the UV-induced suppression of contact hypersensitivity have different wavelength dependencies. J Immunol 1984, 132:2408-2416

14. Rivas JM, Ullrich SE: The role of IL-4. IL-10, and TNF-alpha in the immune suppression induced by ultraviolet radiation. J Leukoc Biol 1994, 56:769-775

15. Byrne SN, Halliday GM: B cells activated in lymph nodes in response to ultraviolet irradiation or by interleukin-10 inhibit dendritic cell induction of immunity. J Invest Dermatol 2005, 124:570-578

16. Matsumura $Y$, Byrne SN, Nghiem D, Miyahara Y, Ullrich SE: A role for inflammatory mediators in the induction of immunoregulatory B cells. J Immunol 2006, 177:4810-4817

17. Rana S, Byrne SN, Macdonald LJ, Chan CY, Halliday GM: Ultraviolet B suppresses immunity by inhibiting effector and memory $T$ cells. Am J Pathol 2008, 172:993-1004

18. Byrne SN, Spinks N, Halliday GM: Ultraviolet-A irradiation of C57BL/6 mice suppresses systemic contact hypersensitivity or enhances secondary immunity depending on dose. J Invest Dermatol 2002, 119: 858-864

19. McGlade JP, Gorman S, Zosky GR, Larcombe AN, Sly PD, FinlayJones JJ, Turner DJ, Hart PH: Suppression of the asthmatic phenotype by ultraviolet B-induced, antigen-specific regulatory cells. Clin Exp Allergy 2007, 37:1267-1276

20. El-Ghorr AA, Horsburgh G, Norval M: The effect of UVB irradiation on antibody responses during herpes simplex virus type 1 (HSV-1) infections of mice. Photodermatol Photoimmunol Photomed 1998, 14: $17-25$

21. Baekkevold ES, Roussigné M, Yamanaka $T$, Johansen FE, Jahnsen FL, Amalric F, Brandtzaeg P, Erard M, Haraldsen G, Girard JP: Molecular characterization of NF-HEV, a nuclear factor preferentially expressed in human high endothelial venules. Am J Pathol 2003, 163:69-79

22. Schmitz J, Owyang A, Oldham E, Song Y, Murphy E, McClanahan TK, Zurawski G, Moshrefi M, Qin J, Li X, Gorman DM, Bazan JF, Kastelein RA: IL-33, an interleukin-1-like cytokine that signals via the IL-1 receptor-related protein ST2 and induces T helper type 2-associated cytokines. Immunity 2005, 23:479-490

23. Allakhverdi Z, Smith DE, Comeau MR, Delespesse G: Cutting edge: the ST2 ligand IL-33 potently activates and drives maturation of human mast cells. J Immunol 2007, 179:2051-2054

24. Suzukawa M, likura M, Koketsu R, Nagase H, Tamura C, Komiya A, Nakae S, Matsushima K, Ohta K, Yamamoto K, Yamaguchi M: An IL-1 cytokine member. IL-33, induces human basophil activation via its ST2 receptor. J Immunol 2008, 181:5981-5989

25. Cherry WB, Yoon J, Bartemes KR, lijima K, Kita H: A novel IL-1 family cytokine. IL-33, potently activates human eosinophils. J Allergy Clin Immunol 2008, 121:1484-1490

26. Bourgeois E, Van LP, Samson M, Diem S, Barra A, Roga S, Gombert JM, Schneider E, Dy M, Gourdy P, Girard JP, Herbelin A: The pro-Th2 cytokine IL-33 directly interacts with invariant NKT and NK cells to induce IFN-gamma production. Eur J Immunol 2009, 39:1046-1055

27. Rank MA, Kobayashi T, Kozaki H, Bartemes KR, Squillace DL, Kita H: IL-33-activated dendritic cells induce an atypical TH2-type response. J Allergy Clin Immunol 2009, 123:1047-1054
28. Alves-Filho JC, Sônego F, Souto FO, Freitas A, Verri WA, AuxiliadoraMartins M, Basile-Filho A, McKenzie AN, Xu D, Cunha FQ, Liew FY: Interleukin-33 attenuates sepsis by enhancing neutrophil influx to the site of infection. Nat Med 2010, 16:708-712

29. Xu D, Jiang HR, Kewin P, Li Y, Mu R, Fraser AR, Pitman N, KurowskaStolarska M, McKenzie AN, McInnes IB, Liew FY: IL-33 exacerbates antigen-induced arthritis by activating mast cells. Proc Natl Acad Sci USA 2008, 105:10913-10918

30. Kondo Y, Yoshimoto T, Yasuda K, Futatsugi-Yumikura S, Morimoto M, Hayashi N, Hoshino T, Fujimoto J, Nakanishi K: Administration of IL-33 induces airway hyperresponsiveness and goblet cell hyperplasia in the lungs in the absence of adaptive immune system. Int Immunol 2008, 20:791-800

31. Miller AM, Xu D, Asquith DL, Denby L, Li Y, Sattar N, Baker AH, McInnes IB, Liew FY: IL-33 reduces the development of atherosclerosis. J Exp Med 2008, 205:339-346

32. Jones LA, Roberts F, Nickdel MB, Brombacher F, McKenzie AN, Henriquez FL, Alexander J, Roberts CW: IL-33 receptor (T1/ST2) signalling is necessary to prevent the development of encephalitis in mice infected with Toxoplasma gondii. Eur J Immunol 2010, 40:426436

33. Kurowska-Stolarska M, Kewin P, Murphy G, Russo RC, Stolarski B, Garcia CC, Komai-Koma M, Pitman N, Li Y, Niedbala W, McKenzie AN, Teixeira MM, Liew FY, Xu D: IL-33 induces antigen-specific IL-5+ $\mathrm{T}$ cells and promotes allergic-induced airway inflammation independent of IL-4. J Immunol 2008, 181:4780-4790

34. Neill DR, Wong SH, Bellosi A, Flynn RJ, Daly M, Langford TK, Bucks C, Kane CM, Fallon PG, Pannell R, Jolin HE, McKenzie AN: Nuocytes represent a new innate effector leukocyte that mediates type-2 immunity. Nature 2010, 464:1367-1370

35. Moussion C, Ortega N, Girard JP: The IL-1-like cytokine IL-33 is constitutively expressed in the nucleus of endothelial cells and epithelial cells in vivo: a novel 'alarmin'? PLoS ONE 2008, 3:e3331

36. Pushparaj PN, Tay HK, H'ng SC, Pitman N, Xu D, McKenzie A, Liew FY, Melendez AJ: The cytokine interleukin-33 mediates anaphylactic shock. Proc Natl Acad Sci USA 2009, 106:9773-9778

37. Cayrol C, Girard J-P: The IL-1-like cytokine IL-33 is inactivated after maturation by caspase-1. Proc Natl Acad Sci USA 2009, 106:90219026

38. Solle M, Labasi J, Perregaux DG, Stam E, Petrushova N, Koller BH, Griffiths RJ, Gabel CA: Altered cytokine production in mice lacking P2X(7) receptors. J Biol Chem 2001, 276:125-132

39. King NJ, Kesson AM: Interferon-independent increases in class I major histocompatibility complex antigen expression follow flavivirus infection. J Gen Virol 1988, 69:2535-2543

40. Kim TY, Kripke ML, Ullrich SE: Immunosuppression by factors released from UV-irradiated epidermal cells: selective effects on the generation of contact and delayed hypersensitivity after exposure to UVA or UVB radiation. J Invest Dermatol 1990, 94:26-32

41. Byrne SN, Halliday GM: Phagocytosis by dendritic cells rather than MHC II(high) macrophages is associated with skin tumour regression. Int J Cancer 2003, 106:736-744

42. Byrne SN, Limon-Flores AY, Ullrich SE: Mast cell migration from the skin to the draining lymph nodes upon UV-irradiation represents a key step in the induction of immune suppression. J Immunol 2008, 180: 4648-4655

43. Daley JM, Thomay AA, Connolly MD, Reichner JS, Albina JE: Use of Ly6G-specific monoclonal antibody to deplete neutrophils in mice. J Leukoc Biol 2008, 83:64-70

44. Stapelberg MP, Williams RB, Byrne SN, Halliday GM: The alternative complement pathway seems to be a UVA sensor that leads to systemic immunosuppression. J Invest Dermatol 2009, 129:2694-2701

45. Rozen S, Skaletsky HJ: Primer3 on the WWW for general users and for biologist programmers. Methods Mol Biol 2000, 132:365-386

46. Damian DL, Barnetson RS, Halliday GM: Low-dose UVA and UVB have different time courses for suppression of contact hypersensitivity to a recall antigen in humans. J Invest Dermatol 1999, 112:939944

47. Bruls WA, Slaper H, van der Leun JC, Berrens L: Transmission of human epidermis and stratum corneum as a function of thickness in the ultraviolet and visible wavelengths. Photochem Photobiol 1984, 40:485-494

48. Piccini A, Carta S, Tassi S, Lasiglié D, Fossati G, Rubartelli A: ATP is released by monocytes stimulated with pathogen-sensing receptor 
ligands and induces IL-1 $\beta$ and IL-18 secretion in an autocrine way. Proc Natl Acad Sci USA 2008, 105:8067-8072

49. Park J, Halliday GM, Surjana D, Damian DL: Nicotinamide prevents ultraviolet radiation-induced cellular energy loss. Photochem Photobiol 2010, 86:942-948

50. Georgiou JG, Skarratt KK, Fuller SJ, Martin CJ, Christopherson RI, Wiley JS, Sluyter R: Human epidermal and monocyte-derived langerhans cells express functional P2X receptors. J Invest Dermatol 2005, 125:482-490

51. Tran JN, Pupovac A, Taylor RM, Wiley JS, Byrne SN, Sluyter R: Murine epidermal Langerhans cells and keratinocytes express functional P2X 7 receptors. Exp Dermatol 2010, 19:e151-e157

52. De Fabo EC, Noonan FP: Mechanism of immune suppression by ultraviolet irradiation in vivo. I. Evidence for the existence of a unique photoreceptor in skin and its role in photoimmunology. J Exp Med 1983, 158:84-98

53. Barber LA, Spandau DF, Rathman SC, Murphy RC, Johnson CA, Kelley SW, Hurwitz SA, Travers JB: Expression of the platelet-activating factor receptor results in enhanced ultraviolet $B$ radiation-induced apoptosis in a human epidermal cell line. J Biol Chem 1998, 273: 18891-18897

54. Tominaga S: A putative protein of a growth specific cDNA from $\mathrm{BALB} / \mathrm{c}-3 \mathrm{~T} 3$ cells is highly similar to the extracellular portion of mouse interleukin 1 receptor. FEBS Lett 1989, 258:301-304

55. Hsu CL, Neilsen CV, Bryce PJ: IL-33 is produced by mast cells and regulates IgE-dependent inflammation. PLoS ONE 2010, 5:e11944

56. Teunissen MB, Piskin G, di Nuzzo S, Sylva-Steenland RM, de Rie MA, Bos JD: Ultraviolet $B$ radiation induces a transient appearance of IL-4+ neutrophils, which support the development of Th2 responses. J Immunol 2002, 168:3732-3739

57. Manetti M, Ibba-Manneschi L, Liakouli V, Guiducci S, Milia AF, Benelli G, Marrelli A, Conforti ML, Romano E, Giacomelli R, Matucci-Cerinic M, Cipriani P: The IL-1-like cytokine IL-33 and its receptor ST2 are abnormally expressed in the affected skin and visceral organs of patients with systemic sclerosis. Ann Rheum Dis 2009, 69:598-605

58. Carriere V, Roussel L, Ortega N, Lacorre DA, Americh L, Aguilar L, Bouche G, Girard JP: IL-33, the IL-1-like cytokine ligand for ST2 receptor, is a chromatin-associated nuclear factor in vivo. Proc Natl Acad Sci USA 2007, 104:282-287

59. Ali S, Nguyen DQ, Falk W, Martin MU: Caspase 3 inactivates biologically active full length interleukin-33 as a classical cytokine but does not prohibit nuclear translocation. Biochem Biophys Res Commun 2010, 391:1512-1516

60. Seki K, Sanada S, Kudinova AY, Steinhauser ML, Handa V, Gannon J, Lee RT: Interleukin-33 prevents apoptosis and improves survival after experimental myocardial infarction through ST2 signaling. Circ Heart Fail 2009, 2:684-691

61. likura M, Suto H, Kajiwara N, Oboki K, Ohno T, Okayama $Y$, Saito H, Galli SJ, Nakae S: IL-33 can promote survival, adhesion and cytokine production in human mast cells. Lab Invest 2007, 87:971-978

62. Suzukawa M, Koketsu R, likura M, Nakae S, Matsumoto K, Nagase H, Saito H, Matsushima K, Ohta K, Yamamoto K, Yamaguchi M: Interleukin-33 enhances adhesion. CD11b expression and survival in human eosinophils. Lab Invest 2008, 88:1245-1253

63. Yagami A, Orihara K, Morita H, Futamura K, Hashimoto N, Matsumoto $\mathrm{K}$, Saito H, Matsuda A: IL-33 mediates inflammatory responses in human lung tissue cells. J Immunol 2010, 185:5743-5750

64. Han W, He YY: Requirement for metalloproteinase-dependent ERK and AKT activation in UVB-induced G1-S cell cycle progression of human keratinocytes. Photochem Photobiol 2009, 85:997-1003

65. Ming M, Han W, Maddox J, Soltani K, Shea CR, Freeman DM, He YY: UVB-induced ERK/AKT-dependent PTEN suppression promotes survival of epidermal keratinocytes. Oncogene 2009, 29:492-502

66. Schmitt DA, Ullrich SE: Exposure to ultraviolet radiation causes dendritic cells/macrophages to secrete immune-suppressive IL-12p40 homodimers. J Immunol 2000, 165:3162-3167

67. Hung K, Hayashi R, Lafond-Walker A, Lowenstein C, Pardoll D, Levitsky H: The central role of CD4(+) T cells in the antitumor immune response. J Exp Med 1998, 188:2357-2368
68. Ullrich SE, Kripke ML: Mechanisms in the suppression of tumor rejection produced in mice by repeated UV irradiation. J Immunol 1984, 133:2786-2790

69. Lucas AD, Halliday GM: Progressor but not regressor skin tumours inhibit Langerhans' cell migration from epidermis to local lymph nodes. Immunology 1999, 97:130-137

70. Agar NS, Halliday GM, Barnetson RS, Ananthaswamy HN, Wheeler $\mathrm{M}$, Jones AM: The basal layer in human squamous tumors harbors more UVA than UVB fingerprint mutations: a role for UVA in human skin carcinogenesis. Proc Natl Acad Sci USA 2004, 101:4954-4959

71. Huang XX, Bernerd F, Halliday GM: Ultraviolet A within sunlight induces mutations in the epidermal basal layer of engineered human skin. Am J Pathol 2009, 174:1534-1543

72. Matthews YJ, Halliday GM, Phan TA, Damian DL: A UVB wavelength dependency for local suppression of recall immunity in humans demonstrates a peak at $300 \mathrm{~nm}$. J Invest Dermatol 2010, 130:1680-1684

73. Calignano A, Cirino G, Meli R, Persico P: Isolation and identification of platelet-activating factor in UV-irradiated guinea pig skin. J Pharmacol Methods 1988, 19:89-91

74. Sreevidya CS, Khaskhely NM, Fukunaga A, Khaskina P, Ullrich SE: Inhibition of photocarcinogenesis by platelet-activating factor or serotonin receptor antagonists. Cancer Res 2008, 68:3978-3984

75. Roth M, Nauck M, Yousefi S, Tamm M, Blaser K, Perruchoud AP, Simon HU: Platelet-activating factor exerts mitogenic activity and stimulates expression of interleukin 6 and interleukin 8 in human lung fibroblasts via binding to its functional receptor. J Exp Med 1996, 184:191-201

76. Grimbaldeston MA, Nakae S, Kalesnikoff J, Tsai M, Galli SJ: Mast cell-derived interleukin 10 limits skin pathology in contact dermatitis and chronic irradiation with ultraviolet B. Nat Immunol 2007, 8:10951104

77. Loser K, Apelt J, Voskort M, Mohaupt M, Balkow S, Schwarz T, Grabbe S, Beissert S: IL-10 controls ultraviolet-induced carcinogenesis in mice. J Immunol 2007, 179:365-371

78. Biggs L, Yu C, Fedoric B, Lopez AF, Galli SJ, Grimbaldeston MA: Evidence that vitamin D3 promotes mast cell-dependent reduction of chronic UVB-induced skin pathology in mice. J Exp Med 2010, 207: 455-463

79. Wolf $P$, Byrne SN, Gruber-Wackernagel A: New insights into the mechanisms of polymorphic light eruption: resistance to ultraviolet radiation-induced immune suppression as an aetiological factor. Exp Dermatol 2009, 18:350-356

80. Cooper KD, Duraiswamy N, Hammerberg C, Allen E, KimbroughGreen C, Dillon W, Thomas D: Neutrophils, differentiated macrophages, and monocyte/macrophage antigen presenting cells infiltrate murine epidermis after UV injury. J Invest Dermatol 1993, 101: 155-163

81. Kurowska-Stolarska M, Stolarski B, Kewin P, Murphy G, Corrigan CJ, Ying S, Pitman N, Mirchandani A, Rana B, van Rooijen N, Shepherd M, McSharry C, McInnes IB, Xu D, Liew FY: IL-33 amplifies the polarization of alternatively activated macrophages that contribute to airway inflammation. J Immunol 2009, 183:6469-6477

82. Strickland I, Rhodes LE, Flanagan BF, Friedmann PS: TNF-alpha and IL-8 are upregulated in the epidermis of normal human skin after UVB exposure: correlation with neutrophil accumulation and E-selectin expression. J Invest Dermatol 1997, 108:763-768

83. Nakagawa S, Koomen CW, Bos JD, Teunissen MBM: Differential modulation of human epidermal Langerhans cell maturation by ultraviolet B radiation. J Immunol 1999, 163:5192-5200

84. Malaviya R, Ikeda T, Ross E, Abraham SN: Mast cell modulation of neutrophil influx and bacterial clearance at sites of infection through TNF-alpha. Nature 1996, 381:77-80

85. Endoh I, Di Girolamo N, Hampartzoumian T, Cameron B, Geczy CL, Tedla N: Ultraviolet B irradiation selectively increases the production of interleukin-8 in human cord blood-derived mast cells. Clin Exp Immunol 2007, 148:161-167

86. Nishida A, Andoh A, Imaeda H, Sugihara T, Inatomi O, Shiomi H, Fujiyama Y: Expression of interleukin-1-like cytokine interleukin-33 and its receptor complex (ST2L and IL-1RAcP) in human pancreatic myofibroblasts. Gut 2009, 59:531-541 